\title{
Financial Stability and Central Bank Governance*
}

\author{
Michael Koetter, ${ }^{\mathrm{a}, \mathrm{b}}$ Kasper Roszbach, ${ }^{\mathrm{c}, \mathrm{d}}$ and \\ Giancarlo Spagnolo ${ }^{\mathrm{e}, \mathrm{f}, \mathrm{g}}$ \\ ${ }^{a}$ Frankfurt School of Finance and Management \\ ${ }^{\mathrm{b}}$ Halle Institute for Economic Research \\ ${ }^{\mathrm{c}}$ University of Groningen \\ ${ }^{\mathrm{d}}$ Sveriges Riksbank \\ ${ }^{\mathrm{e}}$ University of Rome Tor Vergata \\ ${ }^{\mathrm{f}}$ SITE, Stockholm School of Economics \\ ${ }^{\mathrm{g}} \mathrm{CEPR}$
}

The financial crisis has ignited a debate about the appropriate objectives and the governance structure of central banks. We use novel survey data to investigate the relation between these traits and banking system stability, focusing in particular on their role in micro-prudential supervision. We find that the separation of powers between single and multiple bank

*We are grateful to Franklin Allen, Mats Bergman, Mathias Dewatripont, Francesco Giavazzi, Iman van Lelyveld, Enrico Perotti, Marco Pagano, Roberto Rocci, two anonymous referees, the editor (Andy Levin), and participants at seminars at Maastricht University, De Nederlandsche Bank, the 2004 Tor Vergata Conference, the 2006 Bocconi conference on Regulation and Supervision, the 2006 Riksbank conference on the Governance of Central Banks, ASSA-AFA 2007, the 2007 Central Banking Seminar in Cambridge, the Federal Reserve Bank of San Francisco, the 2012 conference on Corporate Governance of Financial Institutions at De Nederlandsche Bank, and the 2013 Bocconi/Finlawmetrics conference on Central Banking, Monetary Stability and Systemic Risk for comments and discussions on both early and more recent versions of work with these data. Particular thanks go to Lars Frisell, with whom Roszbach and Spagnolo conducted the survey underlying this paper. We are also indebted to the BIS and Tonny Lybek at the IMF for making their data available to us, and to David Slutsky, Karl Harmenberg, Harvey Migotti, Mats Levander, and Mattias Quiroz for research assistance. Finally, we thank all central banks that participated in our survey. The views expressed in this paper are solely the responsibility of the authors and should not be interpreted as reflecting the views of the Executive Board of Sveriges Riksbank. In an early stage, fragments of this paper circulated under the title "Governing the Governors: A Clinical Study of Central Banks." Author e-mails: m.koetter@fs.de, kasper.roszbach@riksbank.se, giancarlo.spagnolo@hhs.se. 
supervisors cannot explain credit risk prior to or during the financial crisis. Similarly, a large number of central bank governance traits do not correlate with system fragility. Only the objective of currency stability exhibits a significant relation with non-performing loan levels in the run-up to the crisis. This effect is amplified for those countries with most frequent exposure to IMF missions in the past. Our results suggest that the current policy discussion on whether to centralize prudential supervision under the central bank and the ensuing institutional changes some countries are enacting may not produce the improvements authorities are aiming at. Whether other potential improvements in prudential supervision due to, for example, external disciplinary devices, such as IMF conditional lending schemes, are better suited to increase financial stability requires further research.

JEL codes: G18, G34, G38, E58.

\section{Introduction}

The recent crisis intensified an already open debate on the appropriate set of central banks' objectives and tools, in particular with respect to the prevention and management of future crises. Rethinking the overall financial market regulation, many economists and policymakers are asking whether new tools and mandates for prudential regulation and systemic financial stability should be given to central banks and, if so, then how to regulate the inevitable conflicts between monetary policy, macro-systemic stability, and microsupervisory objectives.

The UK government recently removed the full separation between the Bank of England and micro-prudential supervisory tasks allocated to the Financial Services Authority (FSA) about two decades ago. This separation was considered ineffective in light of the financial crisis, in particular in preventing Northern Rock and the Royal Bank of Scotland from taking too much risk. Part of the supervisory tasks will be moved to a subsidiary of the Bank of England called the Prudential Regulation Authority. The previous separation, however, was introduced in 1997 for the same reason: supervision under the Bank of England was judged ineffective with respect to preventing excessive risk taking at the Bank of Credit 
and Commerce International (BCCI), Barings, etc 11 Moreover, the perception that assigning bank supervision to the central bank is a poor institutional arrangement was so widespread before this crisis that Norway (1900), Sweden (1907), Denmark (1919), and Canada (1925) 2 assigned financial stability tasks to a separate supervisor, and Australia (1998), Japan (1998) 3 Korea (1998), Iceland (1999), Austria (2002), and Germany (2002) transferred some responsibilities out of the central bank (see Herrero and del Rio 2005).

Notable commentators recently suggested that this widespread perception was wrong (and so were all the mentioned institutional reforms), i.e., that it is very important that central banks keep responsibility for financial supervision (e.g., Davies and Green 2010). However, other at least as prominent observers suggest precisely the opposite, i.e., that an independent bank supervision authority is preferable and only the new macro-systemic stability tasks and tools should be assigned to central banks (e.g., Goodhart 2010, Buiter 2011).

The issue is all but obvious, as reasonable theoretical arguments (and models) exist in support of both views. This poses the important empirical question, which institutional arrangement performs better in terms of preventing financial distress, particularly in the wake of a financial crisis: micro supervision to a specialized authority or to the central bank?

In this paper we try to answer this question by looking for empirical support for one policy or the other. We ask if systematic differences across central banks regarding their objectives, supervisory mandate, and some other relevant governance features help to explain banking system fragility prior to and during the crisis. To this end, we use a new survey data set providing detailed information on these central bank traits.

${ }^{1}$ Although the FSA in the United Kingdom adopted its name in 1997, it did not receive its current statutory powers until January 1, 2001.

${ }^{2}$ For Norway, Sweden, Denmark, and Canada we are referring to the establishment of the legal predecessors of the current FSAs. Each of these countries merged its banking supervision authority with one or more other financial sector supervisors between 1986 and 1990 and renamed its national authority.

${ }^{3}$ Until 1998, Japan had a Banking Commission that was an agency of the Ministry of Finance. 
We first describe the pre-crisis situation in terms of microfinancial supervision and the other central bank governance variables for a set of forty-seven central banks as collected through our ad hoc survey 4 Then we focus on credit risk and regress mean shares of non-performing loans (NPL) as a measure of financial fragility on a number of proxies for the governance and institutional traits of prudential authorities.

Univariate analyses show that the correlation between both the governance of supervisory institutions and policy objectives with non-performing loans is weak.

Multivariate regression analyses highlight that only the objective of currency stability exhibits a consistently negative relationship with credit risk prior to the financial crisis. Neither indicators of institutional separation (or unification) of prudential and monetary policy nor proxies for the quality of governance at regulators and central banks influence average credit risk significantly. Overall, a country's legal origin, income dispersion, historical levels of credit risk, and OECD membership explain most of contemporaneous credit risk realizations. For the crisis period itself, however, even these links break down. We find that countries participating in International Monetary Fund (IMF) support programs since 1964 most frequently are significantly more likely to adhere to explicit foreigncurrency objectives. Potentially, the negative relation between currency objectives and lower credit risk in the financial system might therefore reflect an improved and more stringent prudential attitude adopted during longer exposure to disciplining IMF missions.

\subsection{Related Literature}

A large number of authors, starting with the classic papers by Kydland and Prescott (1977), Barro and Gordon (1983), and Rogoff (1985), have investigated how central bank objectives ought to be shaped for the purpose of monetary policy under the risk of political capture by the government and of a consequent political inflationary bias. Persson and Tabellini (1993) and Walsh (1995), among others,

\footnotetext{
${ }^{4}$ Some tables, figures, or regressions may be based on fewer observations because data were not available for - or a question did not apply to - a specific central bank.
} 
have extended this work and studied the optimal contract for independent central bankers 5 Their focus, however, remains limited to "the commitment problem," i.e., to the relevance of independent institutions for optimal monetary policy. Surprisingly, the design of the optimal contract for the supervisory tasks, historically the prime activity of many central banks, the possible trade-offs between monetary policy, financial stability, and banking sector efficiency, as well as the link between central bank independence, accountability, and supervisory performance, have received relatively little attention.

One exception is Taylor and Quintyn (2002), who argue that "regulatory and supervisory independence" is important for financial stability for the same reasons that central bank independence is important for monetary stability. They list a number of dimensions of regulatory and supervisory independence - for example, budgetary freedom-but also contend that for the agency to be fully effective, a supervisor's independence in general needs to go hand in hand with accountability checks. These authors conclude that improper supervisory arrangements have contributed significantly to the deepening of several recent systemic banking crises 6 Still, in these papers the concept of "independence" remains focused on independence from the political process, as a remedy for the risk of capture by the government. On the other hand, the literature on regulatory agencies has emphasized the risk of capture from the regulated firms. Ensuring regulators' independence from the industry they regulate - by, for example, limiting revolving doors arrangements and post-employment possibilities - may therefore be crucial. Considering the enormous pressure to which central bank governors are subjected by the financial sector in crisis situations - e.g., to bail out troubled institutions or to cut interest rates - the need to guarantee this alternative kind of independence appears to have been excessively downplayed by the literature on central banks.

\footnotetext{
${ }^{5} \mathrm{~A}$ rich literature has developed out of these seminal contributions, including recent work such as Keefer and Stasavage (2001), looking into the importance of checks and balances; Eijffinger and Hoeberichts (2002), discussing the need for more transparency in the decision-making process; and Moser (1999), studying the factors that empirically determine independence.

${ }^{6}$ See also Barth, Caprio, and Levine (2004).
} 
The issue of effective central bank governance and regulation besides monetary policy tasks is not of purely theoretical interest, because it can affect the quality of bank regulation and supervision. Giannone, Lenza, and Reichlin (2011) show that the intensity and quality of bank regulation in a country are crucial for explaining the magnitude of damages caused by the recent financial crisis to that country. Abstracting from most recent events, empirical work by Demirguç-Kunt, Laeven, and Levine (2004), Beck, Demirguç-Kunt, and Levine (2006), and particularly Guiso, Sapienza, and Zingales (2007) suggests that through its effect on the allocation of financial resources, the quality of bank regulation and supervision may have dramatic effects on economic growth.

Several previous contributions specifically consider whether it is better to allocate financial supervision to a separate, specialized agency rather than to the central bank. One of the earliest studies that recognize the trade-off faced by a central bank when attempting to attain a multiplicity of goals is Schoenmaker (1992). He acknowledges that a central bank with supervisory responsibility may choose to hold down interest rates because of concerns with the banking system, although purely monetary considerations suggest higher rates. Hence, simultaneously striving for price stability and financial stability involves a time-dependent trade-off. In line with this, Haubrich (1996) and Di Noia and Di Giorgio (1999) present evidence of the inflation rate being higher and more volatile in OECD countries where the central bank also has sole responsibility for banking supervision 7

Peek, Rosengren, and Tootell (1999) study how separating banking supervision from monetary policy influences the effectiveness of the latter. They find that confidential supervisory information on bank ratings significantly improves forecast accuracy of variables critical to the conduct of monetary policy. Their findings highlight the informational synergies often mentioned in support of the argument that central banks should have bank supervision responsibility. However, they do not study how this separation affects the quality of bank supervision.

${ }^{7}$ Whether such a higher rate of inflation is sub-optimal will depend, of course, on the exact weight the government attaches to the bank supervision (financial stability) objective. 
Indeed, the main concern against assigning supervisory tasks to central banks, stressed once again in the recent theoretical analysis by Boyer and Ponce (2012), is the higher risk of regulatory capture it may generate, and appears to have generated in relation to, for example, the savings and loans crisis in the United States and the Barings and BCCI cases in the United Kingdom.

Boot and Thakor (1993) provide another reason why supervisory tasks should be partially or completely separated from the central bank. They show that in the presence of uncertainty about the supervisor's ability (e.g., in evaluating the quality of banks' assets), foreclosing a bank may signal poor monitoring ability. Hence, the supervisor will tend to delay such decisions. Boot and Thakor (1993) suggest that the responsibility for bank closures should therefore be separated from that for asset-quality monitoring. Naturally, efficient separation still requires a mechanism to induce the monitor to truthfully share its information with the regulator.

Kahn and Santos (2005) study the allocation of the lender-of-lastresort function, closure authority (supervision), and deposit insurance. They find that in the multi-regulator arrangement, it is beneficial to assign the supervision mandate to the deposit insurer. The choice between the unified-regulator arrangement and the multiregulator arrangement involves a trade-off: The multi-regulator arrangement reduces the forbearance problem at high levels of liquidity shortage but may exacerbate it at low levels. To our knowledge, there is not yet any empirical research that assesses the costs of supervision in different countries and relates these to the various outputs of the supervisory system (e.g., official warnings, interventions, bank closures).

Finally, Hasan and Mester (2008) look at the effects of a number of central banks' organizational features on some performance indicators in the 1990s, finding little association with the health of the commercial banking system as measured by the percentage of problem loans. They also find, however, that having financial supervision as a main task of the central bank is associated with a worse performance in terms of inflation.

The remainder of this paper is structured as follows. In section 2, we explain our methodology and describe the data. Besides conventional country-specific controls, we present data primarily sourced from our survey on central banks' objectives, mandates, 
and governance structures. Section 3 discusses the results, and we conclude in section 4 .

\section{Methodology and Data}

First, we explain how we measure banking system fragility and control for country traits. Second, we discuss the survey design and present in more detail the data relevant to our study.

\subsection{Fragility and Country Controls}

We use average non-performing loans, a measure of financial system fragility, as our dependent variable. This very simple measure is part of the financial statistics provided by the World Bank and has two main advantages. It is comparable across countries and is considered by both academics and policymakers a key indicator of (excessive) credit risk taken by the banking system of a country 8 We first short-list variables from the data described below, which exhibit the highest univariate explanatory power in OLS regressions. We then specify multivariate regressions with the mean non-performing loan share relative to total loans over the period 2004 until 2006 (pre-crisis NPL) and over the period 2007 until 2009 (crisis NPL). Table 1 provides descriptive statistics and results from univariate OLS for all variables considered, which serve as a selection device of covariates in multivariate analyses.

Before turning to the (mostly) survey-based central bank traits, we briefly present the country controls specified in the cross-sectional regressions. The sample size is at most forty-five, which is determined by the authorities (countries) responding to the survey. Appendix 1 shows all forty-four countries and the European Central Bank (ECB) considered here.

Better enforceability of contracts and protection of creditors should generally correlate negatively with the share of NPL. We measure the level of creditor rights suggested initially by La Porta et al. (1998). We obtain data for the years 2001 and 2008 from the

\footnotetext{
${ }^{8} \mathrm{We}$ also considered capitalization ratios and z-scores (Laeven and Valencia 2010), both of which corroborate the absence of results that we report below. Results are available upon request.
} 


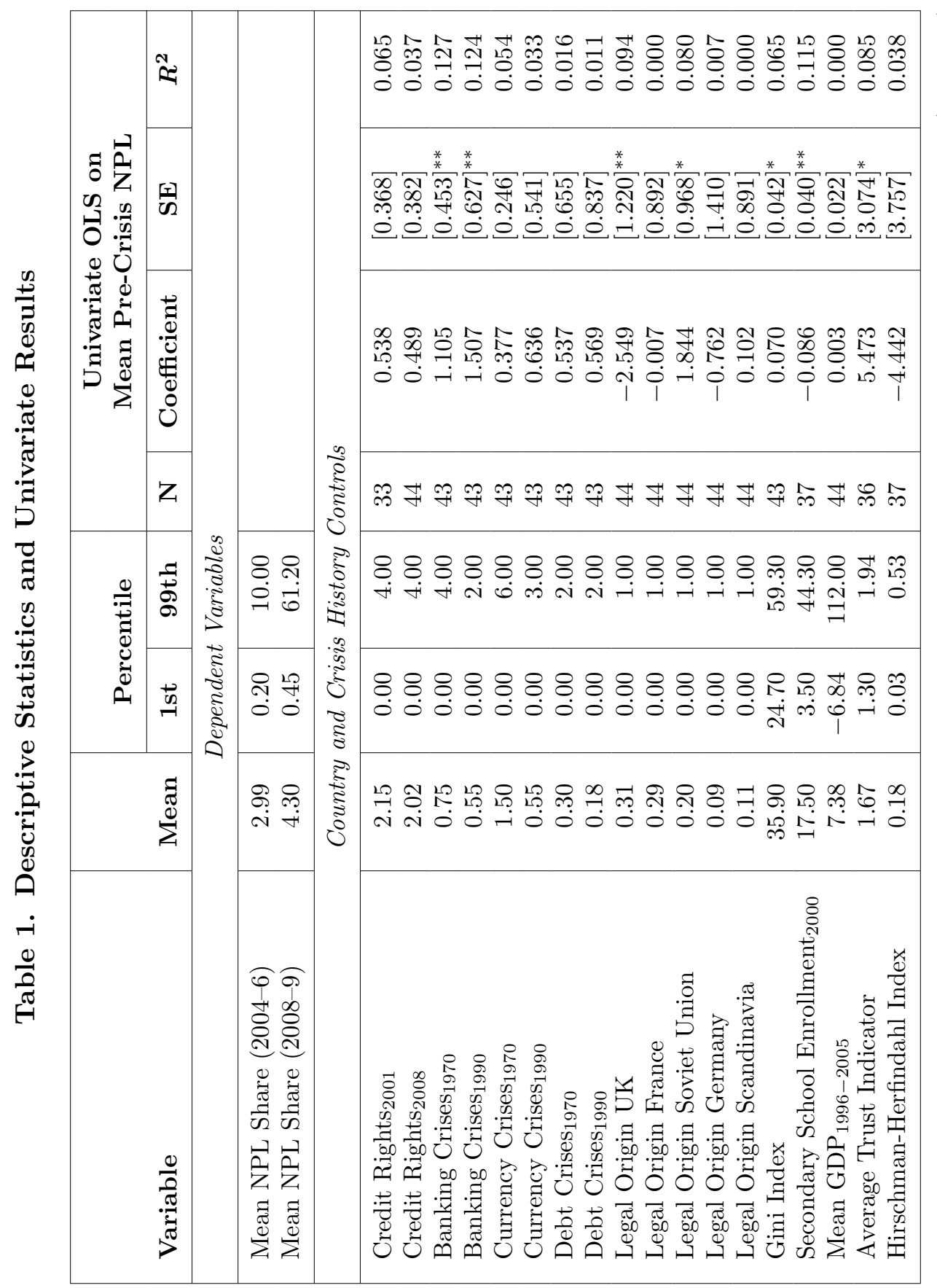




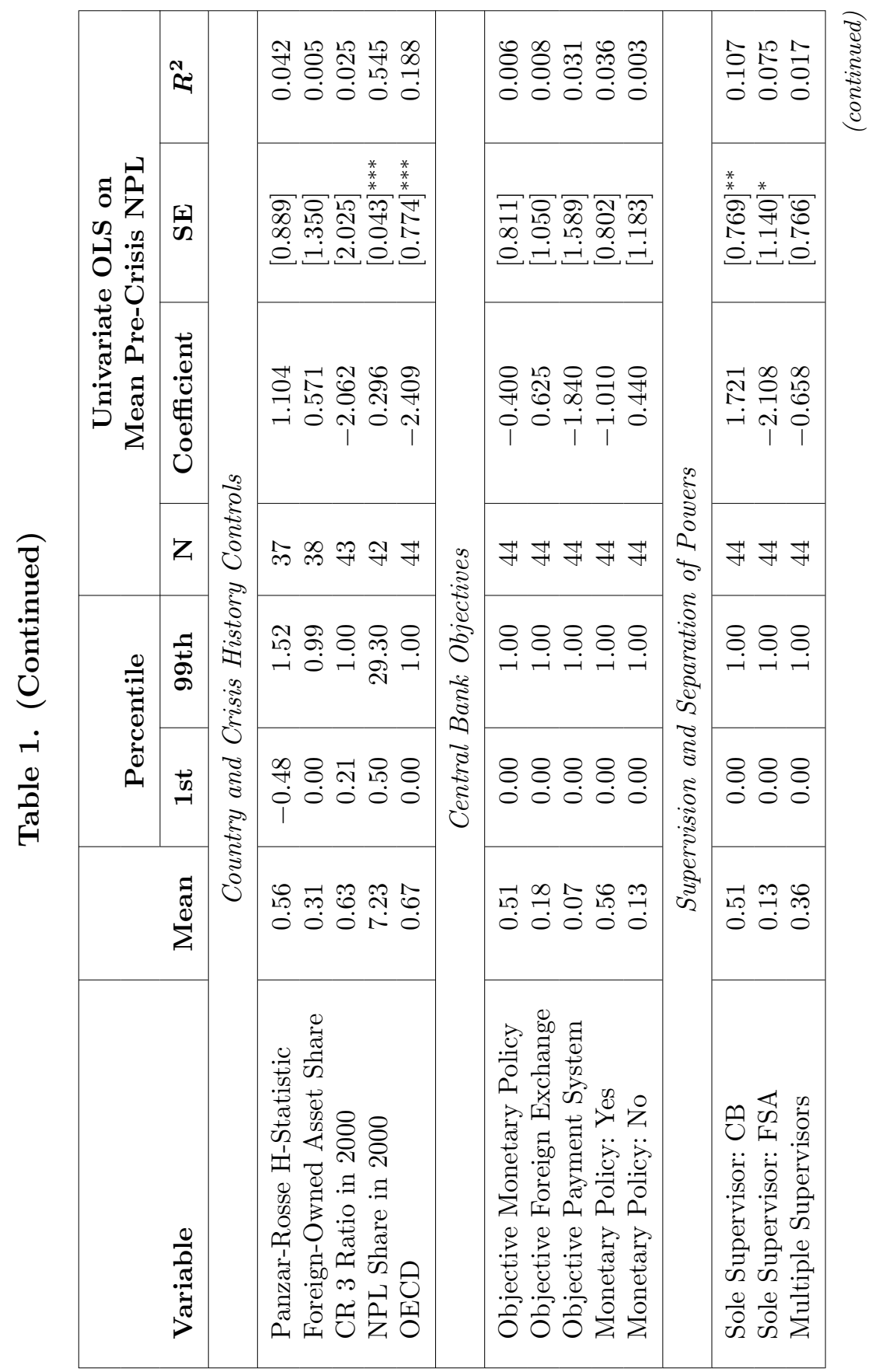




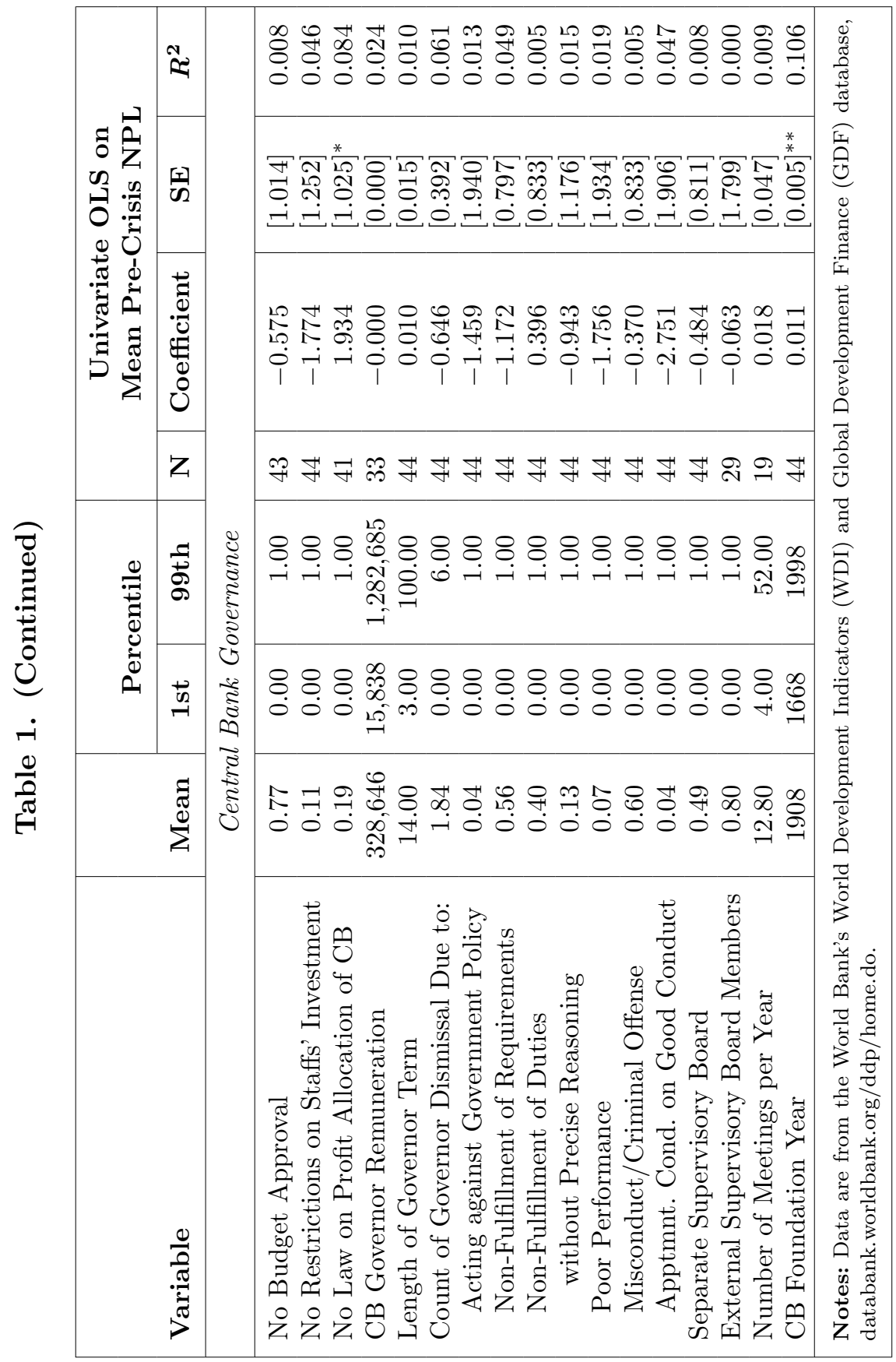


website of Andrei Shleifer.The variable is an index that ranges from 0 to 4 in our sample, where higher values indicate better creditor rights. Univariate results in table 1 indicate that creditor rights do not correlate with NPL shares. We disregard the variable in multivariate analysis.

A country's history of crises may increase risk adversity of agents and improve prudential monitoring procedures subsequently. But it might also create path dependency if it takes long-lasting efforts to restore trust in financial markets. We therefore include a count variable for three types of crisis sourced from Laeven and Valencia (2010): banking crises, currency crises, and debt crises. We specify two counts. The first starts in 1970 and the second starts in 1990. Only banking crises correlate significantly and positively with pre-crisis NPL shares, which indicates that bad debt is persistent.

Next, we control for the differences in legal origins across countries (also obtained from the home page of Andrei Shleifer). Given the limited degrees of freedom due to the number of countries studied here, we specify in the multivariate analyses below only one dummy that is significant in univariate analysis, namely for countries with a legal UK heritage. Relative to any other legal heritage, UK-type legal systems exhibit lower levels of NPL shares in our sample.

To control for the differences in income and economic activity across countries, we tested a number of conventional macro indicators provided in the World Development Indicators of the World Bank, such as gross domestic product (GDP), GDP per capita, GDP growth across various time episodes, etc. We show in table 1 the descriptive statistics for the specified measure of income dispersion across countries, the Gini coefficient, which is weakly positively correlated with NPL shares. Higher values indicate a larger dispersion of income within a country. We also show the share of students enrolled in secondary education in the total population as a measure of human capital intensity as well as mean GDP between 1996 and 2005. Both variables are excluded below due to high correlation with the Gini coefficient and limited degrees of freedom in multivariate analysis.

Trust is another potential determinant of deciding whether to extend a loan, as well as the risk of the latter turning non-performing. We use a measure from the World Value Survey 
questionnaire also used in, for instance, Guiso, Sapienza, and Zingales (2008). It gauges how much people generally think others can be trusted. Higher values indicate larger skepticism. Despite univariate significance, we excluded the covariate from multivariate analysis below because of high correlation with other country controls and fairly low coverage of sampled countries.

Many studies discuss the relation between banking market structure, competition, and risk (see, e.g., Keeley 1990, Koetter and Poghosyan 2009, and Martínez Miera and Repullo 2010). We therefore test simple measures of concentration (Hirschman-Herfindahl indices and concentration ratios) and competition measures (PanzarRosse H-statistics), as well as the share of foreign-owned banks' assets. None of these correlates significantly with mean NPL shares. We nonetheless include one proxy in the multivariate regressions below given the ample indications in previous literature that competition and market structure are important in explaining the risk taking of banks.

Bad credit is persistent and we expect that historically high levels of NPL shares are unlikely to vanish quickly. Therefore, we also specify the NPL share in the year 2000, which exhibits a significantly positive univariate effect on mean NPL shares in the three years prior to the crisis. Finally, we account for OECD membership in this fairly heterogeneous sample of countries by including an according indicator variable. OECD membership is also statistically significant and correlates negatively with mean NPL shares.

\subsection{Survey Data on Central Banks}

In spring 2004 we formulated a list with nineteen composite questions regarding the governance characteristics of a central bank. We refer to appendix 1 for the complete list. The questions broadly focused on five areas: (i) the objectives and tasks of the bank, and the exclusivity of its responsibilities; (ii) ownership structure, budgetary freedom, and restrictions on the allocation of profits; (iii) the appointment, remuneration, tenure, and dismissal of governors; (iv) the appointment, tenure, and dismissal of supervisory board members; and (v) limitations on investments by bank staff and governors. In this paper, we use data from areas (i) and (ii). 
To the extent that central banks provided information on the above-mentioned areas, we collected the answers to these questions from the websites of forty-seven central banks between June and August 2004. Between June and August 2005, we checked the websites once more to verify if more data was available.

The starting point for our sample consisted of all thirty-one members and two candidate members of the OECD as of 2005 and all but one G20 members that are not OECD members (nine). To come closer to a sample size of about fifty countries, we added four developed or emerging Asian economies as well as an EU candidate member.

On September 16, 2005, we followed up on the first step of the data collection by sending out a written questionnaire to all fortysix central banks with a request for relevant information that was not provided on the banks' websites 9 Surveys were individualized in the sense that questions to which we already had answers were deleted from the "gross" list. In case a central bank had a research department at that point in time, we sent the survey to the director of research. For the remaining central banks, we directed the form to the respective heads of the economics department or to what appeared to be the nearest alternative. Addresses, departments, and contact persons were taken from the Bank for International Settlement's (BIS's) International Directory of central banks, which is updated monthly by the BIS. Each questionnaire was accompanied by a letter (appendix 2). Central banks were asked to return the form by October 6, 2005.

By October 6, 2005, we had received replies from four of the fortyseven central banks, although by October 13, this number had risen to fourteen. On November 1, 2005, we sent out a reminder letter by regular mail to the twenty-six central banks that had not yet replied. If we were able to find the e-mail address of the addressee on the Internet, we also sent a copy of the reminder by e-mail. Within the four weeks after this reminder, we received another nine replies, making the total, including Sweden, twenty-nine. Another four central banks had confirmed receipt of the questionnaire, without sending a reply, one of which replied they would not be able to answer the questions.

\footnotetext{
${ }^{9}$ No survey was sent to the Riksbank.
} 
Between December 2005 and June 2006, one more bank confirmed receipt of the survey without replying. On June 19, 2006, we sent a second reminder by e-mail to the remaining sixteen banks and followed up with a phone call within a week. This resulted in another eleven responses. A personal letter we sent to the governor or a deputy governor of three central banks on July 5, 2006 led to another two replies. By September 4, 2006, we had the replies from forty-three of the forty-seven central banks and concluded our data collection effort.

For eight central banks, the answer to at least one sub-question was missing or incomplete in the reply. In those cases, we contacted the respondent with a request for a completion and attempted once more to locate the information on the website of that bank. For some variables and central banks, omitted replies indicated that a question did not apply. For some others it indicated unwillingness to reply and/or an inability by us to obtain an answer-for example, because we did not get the complete answer after a reminder. In the final data set, for example, nine countries did not fill out an answer to the question about governor wages. In sections 2.2.1 through 2.2.3 below, we briefly discuss the survey results we use in this study. For more information, we refer to a predecessor of this paper-Frisell, Roszbach, and Spagnolo (2008) - where the full survey data set is discussed.

\subsubsection{Central Bank Objectives}

We define three groups of objectives from these responses. First, we code an indicator variable for monetary policy objectives if authorities replied that they pursue price stability or monetary stability. Second, we specify a dummy for foreign exchange objectives if central banks respond that they aim to preserve either the external value or the stability of the purchasing power of the currency. Third, we specify payment system stability as the objective if central banks indicate to ensure an efficient functioning of payment systems or guide sound banking operations.

As figure 1 shows, these three objectives jointly apply to 70.2 percent of the sampled countries. Roughly 50 percent of the banks indicate that price or monetary stability is their main objective, just over 8 percent that they have an efficient payments system or 


\section{Figure 1. Objectives of Central Banks}

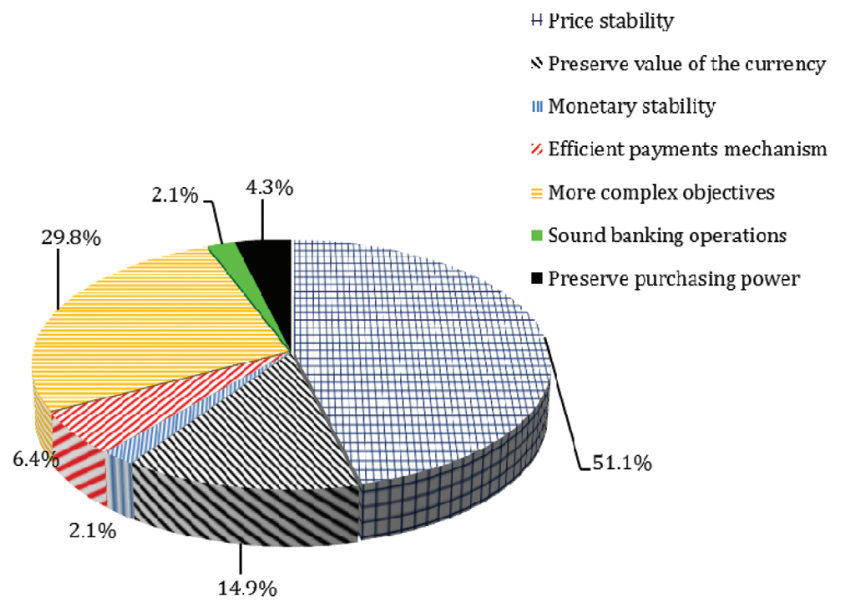

Notes: Replies from questionnaire; see appendix 1 for details. Multiple replies per central bank are possible $(N=47)$.

banking system stability as their objective, and 18 percent that they have a forex objective. The remaining central banks indicate more complex objectives. The data in table 1 demonstrate that none of these objectives exhibits significant univariate explanatory power. We test for potential multivariate effects below. We also test whether the simple indicator "monetary policy is stipulated in the central bank law as the prime objective" can explain mean NPL shares and find this indicator is also uncorrelated.

\subsubsection{Separation of Powers}

We specify three categories to test for different arrangements regarding the separation of power. The first dummy indicates that a country has only one supervisor, namely the central bank. Of all countries, 51 percent belong to this category. The second dummy equals 1 for countries with just one supervisory authority but where an institution other than the central bank, such as a financial supervisory agency, fulfills this function. Thirteen percent are in this category. A third dummy variable captures jurisdictions with multiple supervisors. This regime applies to more than one out of three jurisdictions. 
Univariate regressions indicate that centralized supervision correlates with NPL shares. If central banks act as the sole prudential supervisor, mean NPL shares prior to the crisis are higher. Sole responsibilities resting with an independent authority different than the central bank correlates negatively with NPL shares.

In contrast to objectives as such, differences in mandates thus seem to bear explanatory power for NPL shares. Below, we will explore this possible link in more detail using multivariate analysis.

\subsubsection{Governance and Independence}

Commonly used measures of central bank independence take into account to what extent a bank can conduct monetary policy without a formal possibility for parliament or the government to influence decision making. In our survey and in this paper, we instead attempt to capture to what extent central banks can be considered financially independent from the political sphere. In particular, when studying the impact of the institutional structure of financial supervision on financial system stability, such measures better capture the relevant governance features of a central bank and the leeway it has to conduct stabilizing operations in financial markets. Our survey therefore focused on a bank's freedom to allocate and distribute profits, as well as on its freedom to set its own budget. Such rights are likely to influence the ability of a central bank to adjust the size and composition of its balance sheet when conducting financial stability policy. Figure 2 contains data on the freedom that central banks have to allocate profits. In our survey 11 percent report that there are no laws governing the allocation of profits, while an equal share reports that the allocation of profits is governed by law. The vast majority reports a more complex solution-for example, with informal arrangements or through regulations other than by law.

With regards to their budgets, central banks have more freedom. As displayed in figure 3, three out of four report that they do not need approval from parliament or the government, the typical principals of central banks.

We tested a large number of governance indicators from the survey, shown in the bottom panel of table 1, on a relation with two banking system stability measures. With the exception of two indicators, none correlates with observed NPL shares. We discuss here 
Figure 2. Are Any Laws Set upon Central Banks that Govern How Profits Should Be Allocated?

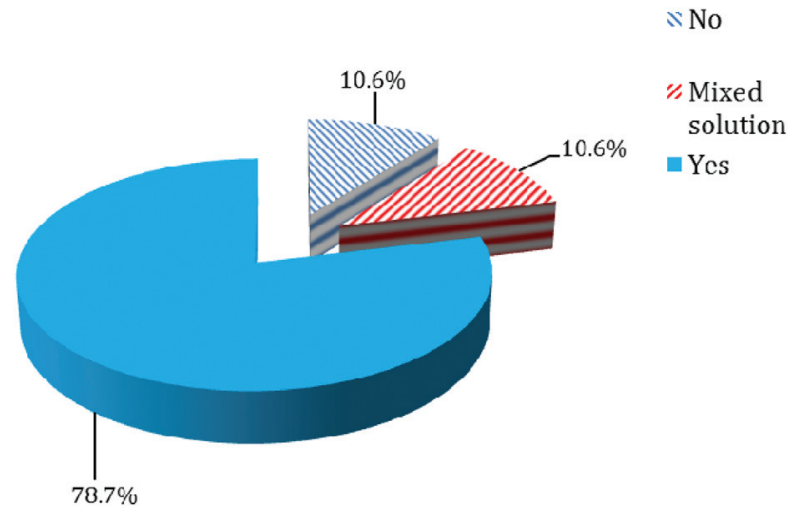

Notes: Replies from questionnaire; see appendix 1 for details. $(N=47)$.

Figure 3. Do Central Banks Need Approval from Parliament or the Government before Setting Their Budget?

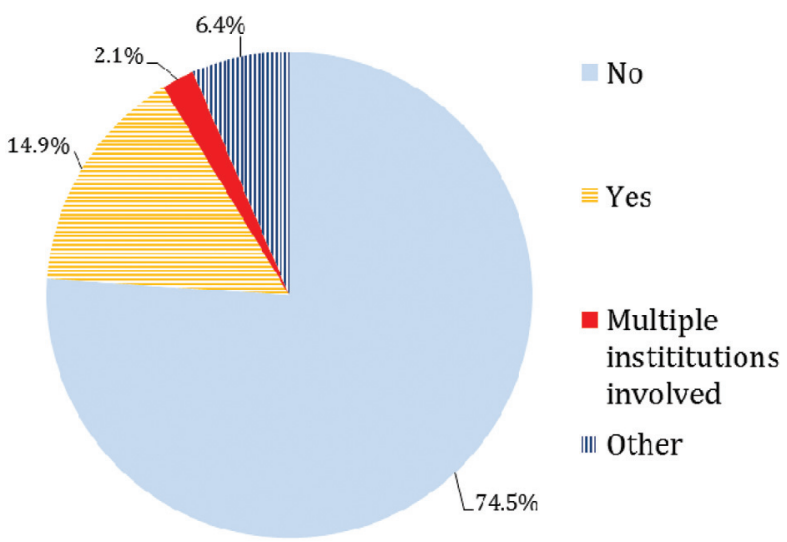

Notes: Replies from questionnaire; see appendix 1 for details. $(N=47)$.

only the three measures we include in the multivariate regressions below.

First, we include a dummy indicating that the government or legislature does not have to approve central banks' expenditure budget. 
Budget autonomy indicates higher central bank independence and should thus indicate that it is better safeguarded from political influence. Second, we specify an indicator equal to 1 if no law exists that governs the allocation of central bank profits. This variable indicates higher financial independence and correlates weakly, but positively, with mean NPL shares. Third, we find that a more recent foundation data of central banks is positively related to NPL shares prior to the crisis. Younger central banks may correlate positively with NPL shares if a shorter history of the institution gauges also less experience and skill. In contrast, younger central banks might have fewer vested interests - for instance, resulting from entanglement of former supervisors with the commercial banking sector-and therefore could reduce NPL shares after controlling for other factors. Thus, the effect of central banks' foundation years on NPL shares in a multivariate context remains a priori ambiguous.

Other measures of central bank governance - such as the level of pay, the existence and composition of supervisory boards, the meeting cycle, terms lengths, or differently motivated dismissals of governors - show no significant univariate correlation with NPL for our sample.

\subsection{Auxiliary Data}

In addition to the data from our questionnaire and the country controls described above, we used data from three other sources: a list of regulatory authorities and supervisory agencies maintained by the BIS (BIS 2005), central bank governance data collected by the IMF (Lybek and Morris 2004; Berger, Nitsch, and Lybek 2006), and the Electronic Compendium on Central Bank Governance maintained by the BIS Central Bank Governance Forum (BIS 2004). In addition, we collected the founding year of each central bank from its respective website.

We used the BIS list of regulatory authorities and supervisory agencies to cross-check and supplement information provided by central banks on the importance and exclusivity of their supervisory tasks. For countries we did not have first-hand knowledge on, we verified the data on the BIS website to make sure the list was up to date. All three supervision and separation of power variables ("Sole Supervisor: CB," "Sole Supervisor: FSA," "Multiple Supervisors") 
were constructed using this information. Because we only used the other BIS and IMF data in exploratory analyses, but not in any of the results we present in the paper, it suffices here to refer to the above articles for a description of these data.

\section{Results}

As discussed in the literature review, there are arguments in favor of and against separating financial supervision from other tasks typical of central banks, but most theoretical analyses appear to suggest that the benefits from separation are likely higher than the costs. Many recent policy papers and statements from central banks and the current UK government argue instead in the opposite direction. Empirical evidence is lacking, as the study closest to ours, Hasan and Mester (2008), finds no significant effect of this feature for the pre-crisis period. Here, we test whether the consideration of the crisis period paired with the specification of our novel survey response data reported directly by central banks themselves sheds a different light on the issue.

\subsection{Pre-Crisis Credit Risk}

Table 2 shows results from OLS regressions of non-performing loan (NPL) shares averaged over the period 2004 until 2006 for each country 10 Column 1 presents results for a specification including all covariates that are significantly different from 0 in univariate tests and a number of test variables added at our discretion 11 The first panel illustrates that neither more frequent crises in the past, nor banking market structure, influence mean NPL shares as such. Higher income dispersion and high historical levels of NPL explain

\footnotetext{
${ }^{10} \mathrm{We}$ also specified annual estimations and various different time intervals. Results are qualitatively unaffected. Our preference for the period 2004-6 results from the timing of the questionnaire (mostly around 2005), a sufficiently long time lag to historical NPL levels (2000 in our case), and the aim to have a symmetric crisis time window (2007-9; see next sub-section). All alternative specifications are available upon request.

${ }^{11}$ We tested a battery of different combinations, using stepwise regression to exclude or include alternative covariates for each of the four "blocks" in the regressions.
} 
Vol. 10 No. 4 Financial Stability and Central Bank Governance

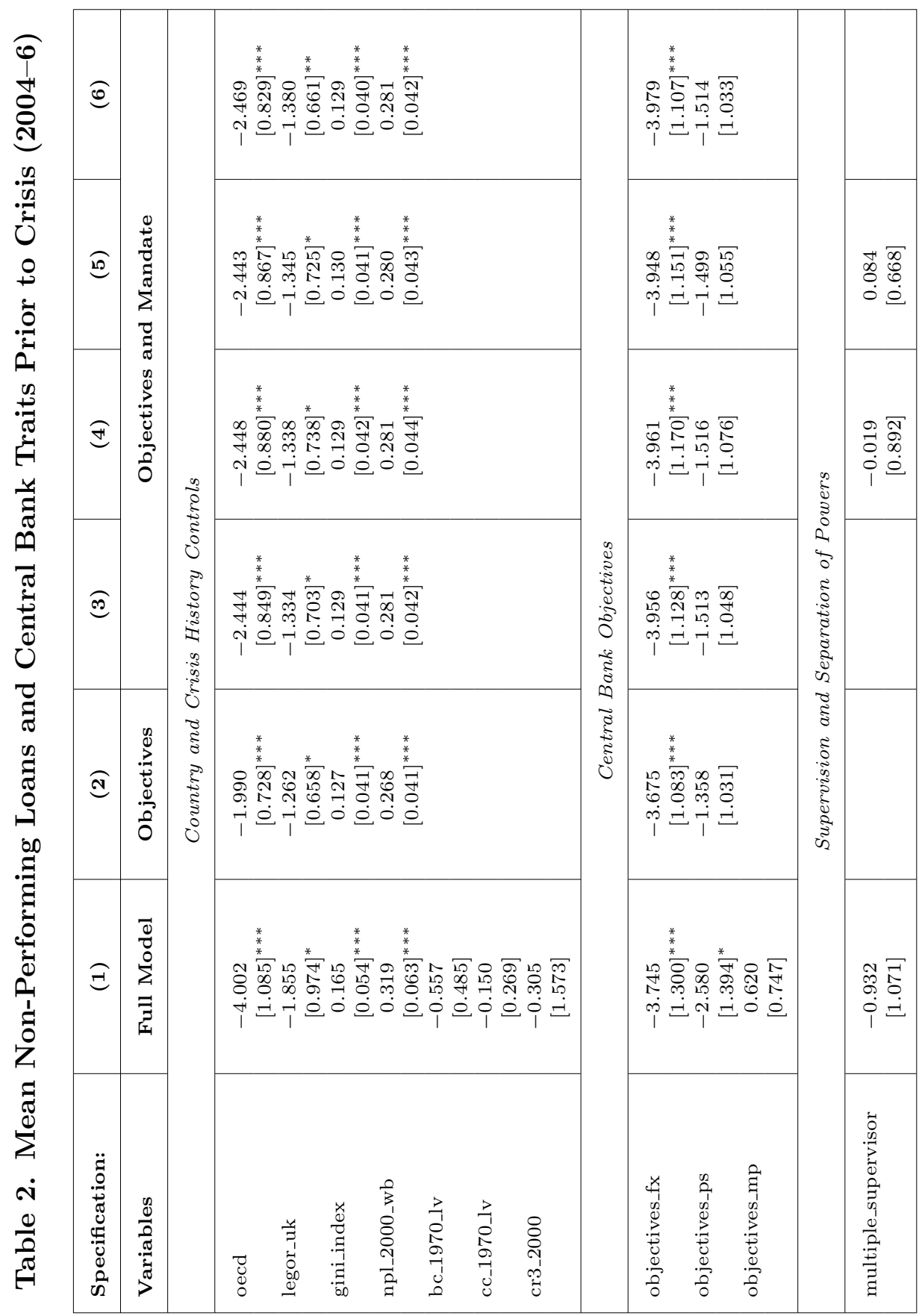




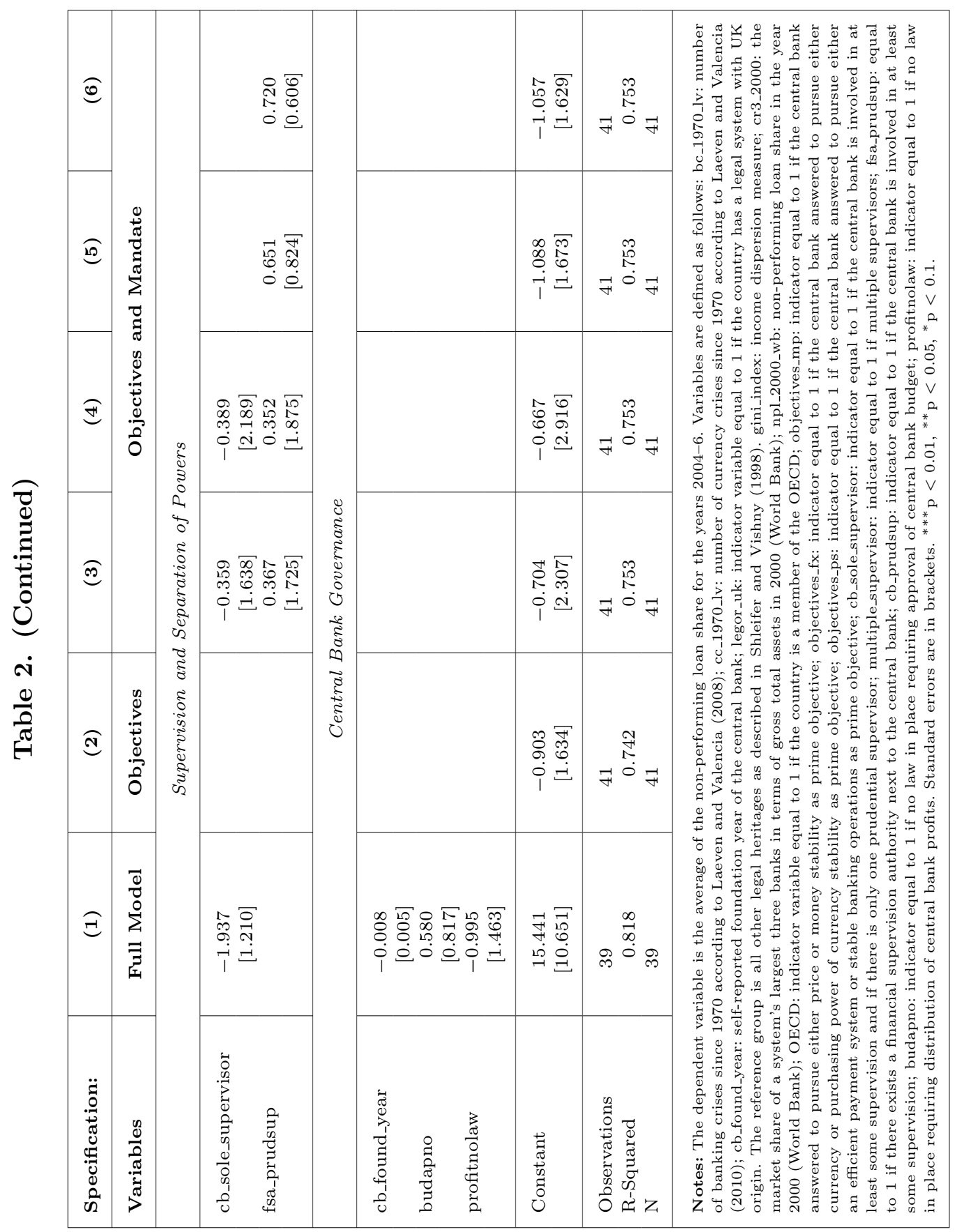


a large part of the cross-country variation and correlate positively with pre-crisis NPL shares. Membership in the OECD and a legal system with a UK heritage reduces NPL shares.

The second panel shows that objectives do matter for credit risk as well. However, in contrast to univariate analysis, the objective of monetary policy exhibits no significant relation. In fact, pursuing external stability as a prime objective correlates most significantly, and negatively, with pre-crisis NPL shares. The third panel further shows that differences in the prudential supervisory architecture across sampled economies have no significant influence on NPL shares. Likewise, models with interactions terms between objectives and supervisory architecture differences (not reported) yield no significant differential effect of certain combinations between the two sets of variables.

Hence, much of the ongoing debate on whether to centralize prudential supervision, the potential role of central banks versus alternative authorities, and the potential interplay between price and financial stability objectives appears less relevant than expected.

Regarding central bank governance proxies shown in the bottom panel of table 1 , we also fail to detect significant relations with NPL shares. Overall, macroeconomic differences across countries are most relevant to explain credit risk.

The lack of significant relations before and during the crisis is consistent with the negative findings of Hasan and Mester (2008) for the non-crisis period in the 1990s. However, the absence of results might merely reflect the fairly low degrees of freedom in our sample. Therefore, we test in columns 2-6 whether our findings are corroborated when excluding insignificant covariates. Consider first specification (2), which scrutinizes the results for central bank objectives and drops any prudential supervision, governance, or insignificant macro covariate. The negative relation between foreign stability objectives and NPL shares is corroborated, but the previously weak significance regarding payment system stability vanishes. We investigate below whether this NPL-reducing effect of foreign stability objectives potentially reflects past experiences with IMF missions. IMF involvement might have caused generally higher standards of policy procedures at central banks that eventually also affected NPL levels positively. 
Let us first consider a number of permutations in columns 3 6 that augment the reduced specification with different combinations of prudential mandate indicators. We focus on these variables because of the intense policy debate (and actions) reflected by, for instance, the enactment of the Dodd-Frank bill in the United States and the inception of the European Systemic Risk Board under the auspices of the ECB that intend to establish autonomous and centralized prudential supervisory institutions. In short, none of the specifications indicate any significant correlation between differences in prudential mandates across sample countries and NPL shares. Hence, this finding confirms that the current policy debate might be misguided to the extent that alternative arrangements did not affect pre-crisis NPL shares in the first place.

\subsection{Crisis Credit Risk}

A possible explanation for the absence of any such effect might be that NPL shares in "normal" times just prior to the crisis were monitored equally (in)effectively by either prudential architecture. Therefore, table 3 shows identical specifications as table 2using, however, the mean share of NPL during the crisis, specifically between 2007 and 2009 .

The ability of the previously chosen covariates to explain NPL shares vanishes almost entirely. Only the number of currency crises since 1970, higher banking market concentration, and more recent foundation of the central bank exhibit statistically weak evidence in favor of lower NPL ratios. This result vividly illustrates that during the crisis the institutional arrangements are of even lesser importance. Presumably, the statement of objectives of central banks might have meant little in times of crisis when authorities around the globe took unusual measures to support crippled financial systems (see, e.g., Stolz and Wedow 2010 for a survey of "unconventional" measures during the crisis). Likewise, the existence of single or multiple supervisors is likely to mean little in times of international ad hoc collaboration among representatives from all authorities, including top-level government representatives, to stabilize financial systems in concerted efforts. 
Vol. 10 No. 4 Financial Stability and Central Bank Governance

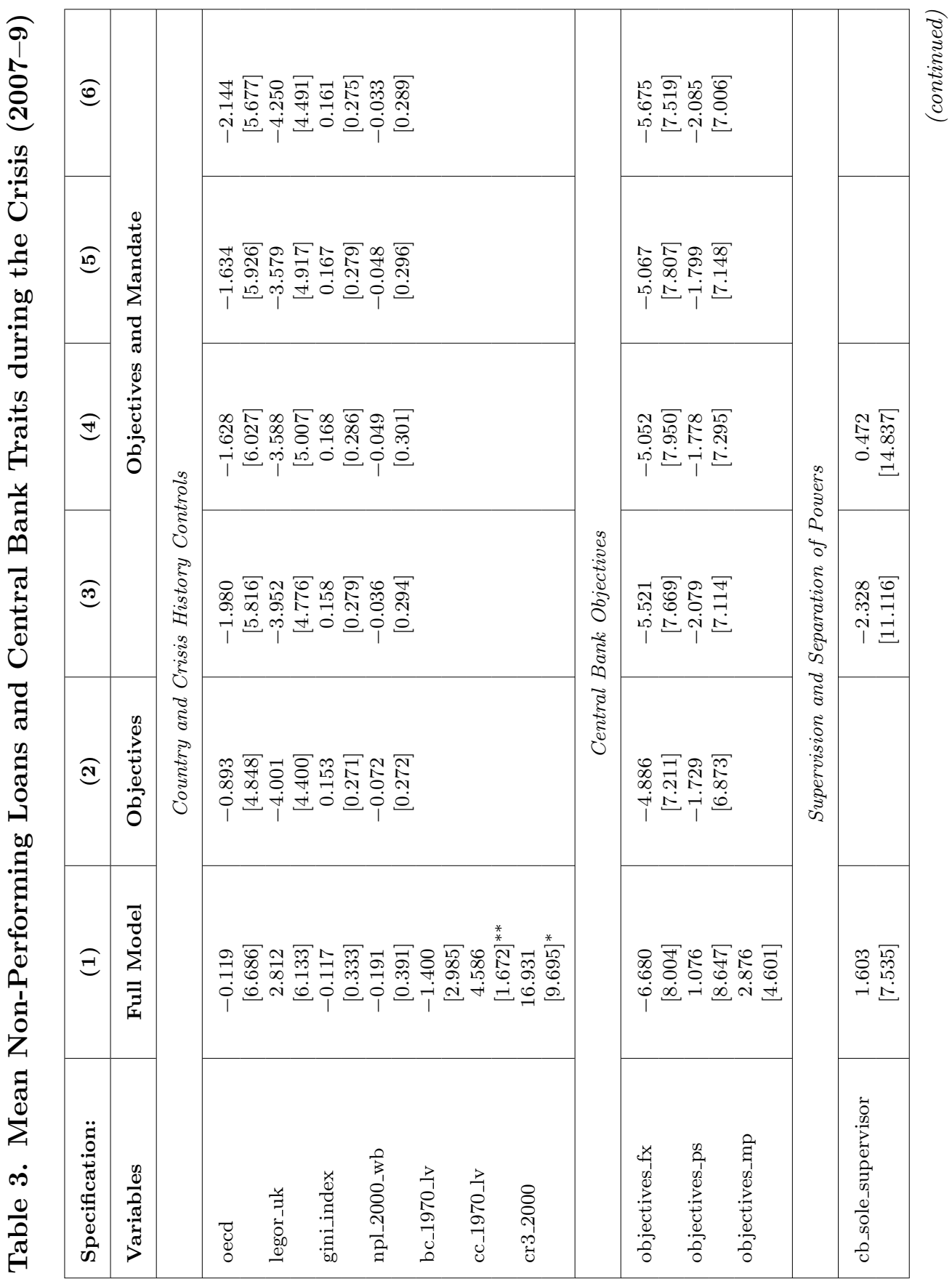




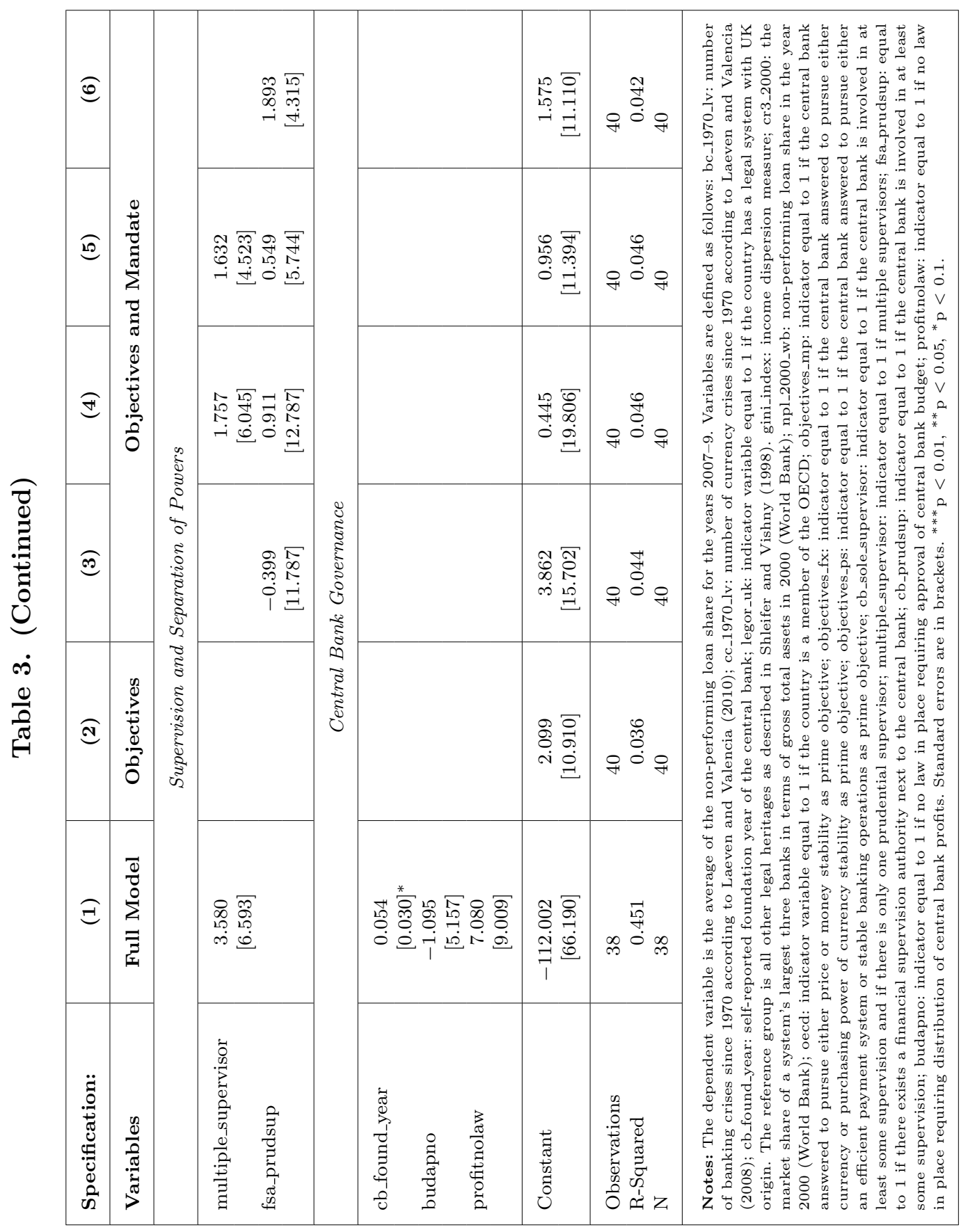




\subsection{Why Currency Stability Objectives?}

The result that pre-crisis NPL shares are basically only correlated with the existence of explicit objectives of central banks to maintain a stable currency warrants some further discussion.

A first potential reason could be that governments in countries that pursue fixed exchange rate regimes are more prone, and powerful, to prick (perceived) bubbles as they emerge. Such differences in intrusive policy propensity and ability might partly be captured by indices of economic freedom. Table 4 shows according regressions where we specify each of the five individual freedom index components as well as a summary index collected since 1970 by the Fraser Institute for a comprehensive sample of countries (Gwartney, Lawson, and Gartzke 2005) 12 Each pair of columns refers to NPL prior to the financial crisis $(2004-6)$ and during the financial crisis (2007-9) as dependent variable, respectively. The result that pre-crisis credit risk is negatively associated with a foreign exchange objective of the central bank remains intact. Likewise, NPL levels during the crisis continue to remain not significantly affected by stated objectives of central bankers. Hence, foreign exchange objectives are unlikely to merely gauge potentially omitted differences in government's hesitance to regulate banks.

Another potential reason why the objective to maintain a stable currency coincides with lower levels of NPL shares could result from a larger exposure to external disciplining devices. One such device could, in our view, be the involvement of the IMF once it extends a loan to a country. IMF lending is usually conditioned on complying with procedures to select and monitor investment projects funded with IMF support. We also assume that IMF missions at central banks of countries having received support occur more often in order to ensure a proper management of IMF funds independent of political interests, e.g., by the ministry of finance. IMF staff presence might either directly or indirectly improve governance and processes at central banks - for instance, through training and skill transfers or simply by setting an example on acting prudently and

\footnotetext{
${ }^{12}$ The sub-components of the index are listed in table 6. Data pertain to the survey year 2005 to match the survey year of central banks. Data have been obtained from http://www.freetheworld.com/.
} 


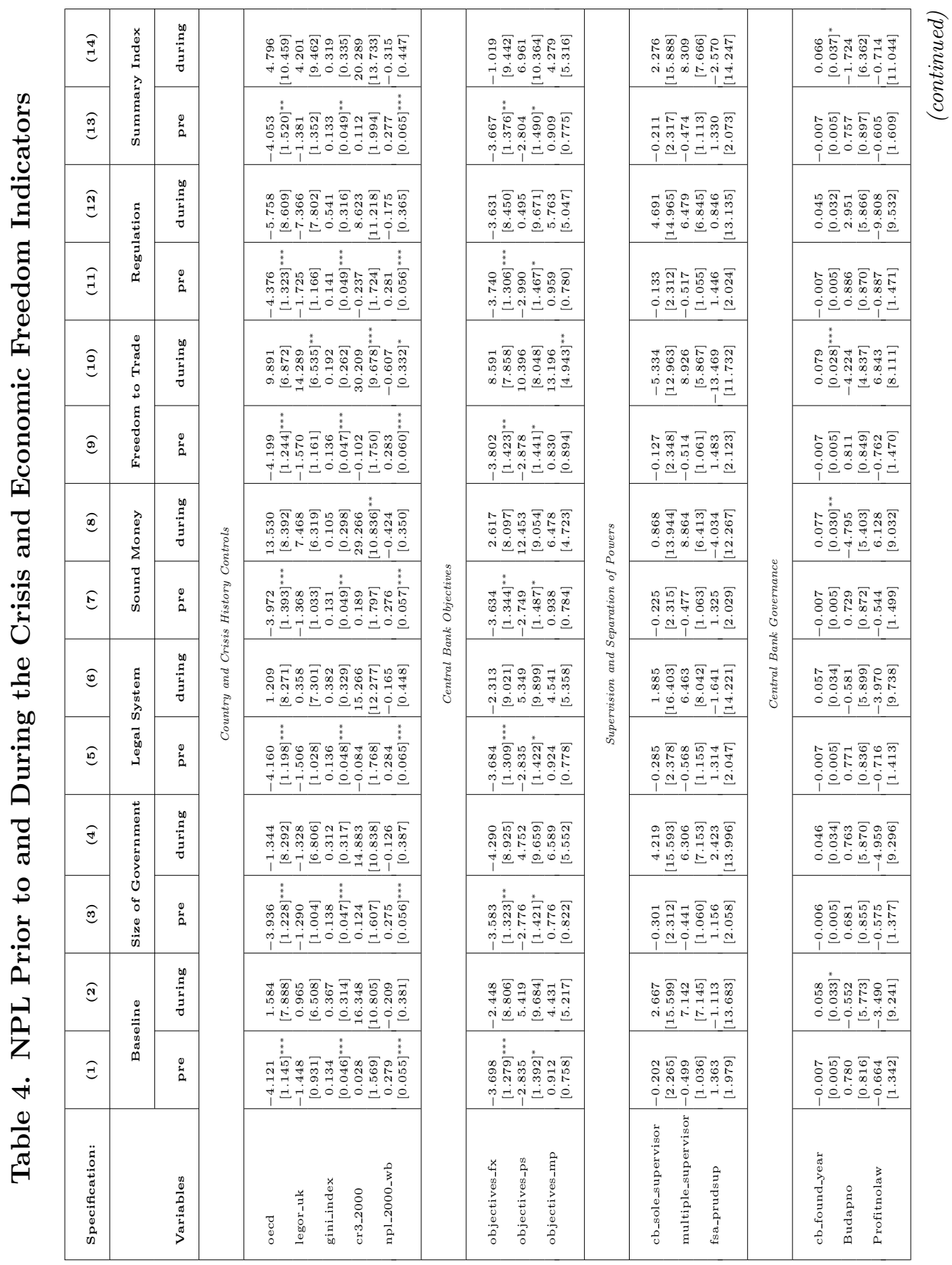




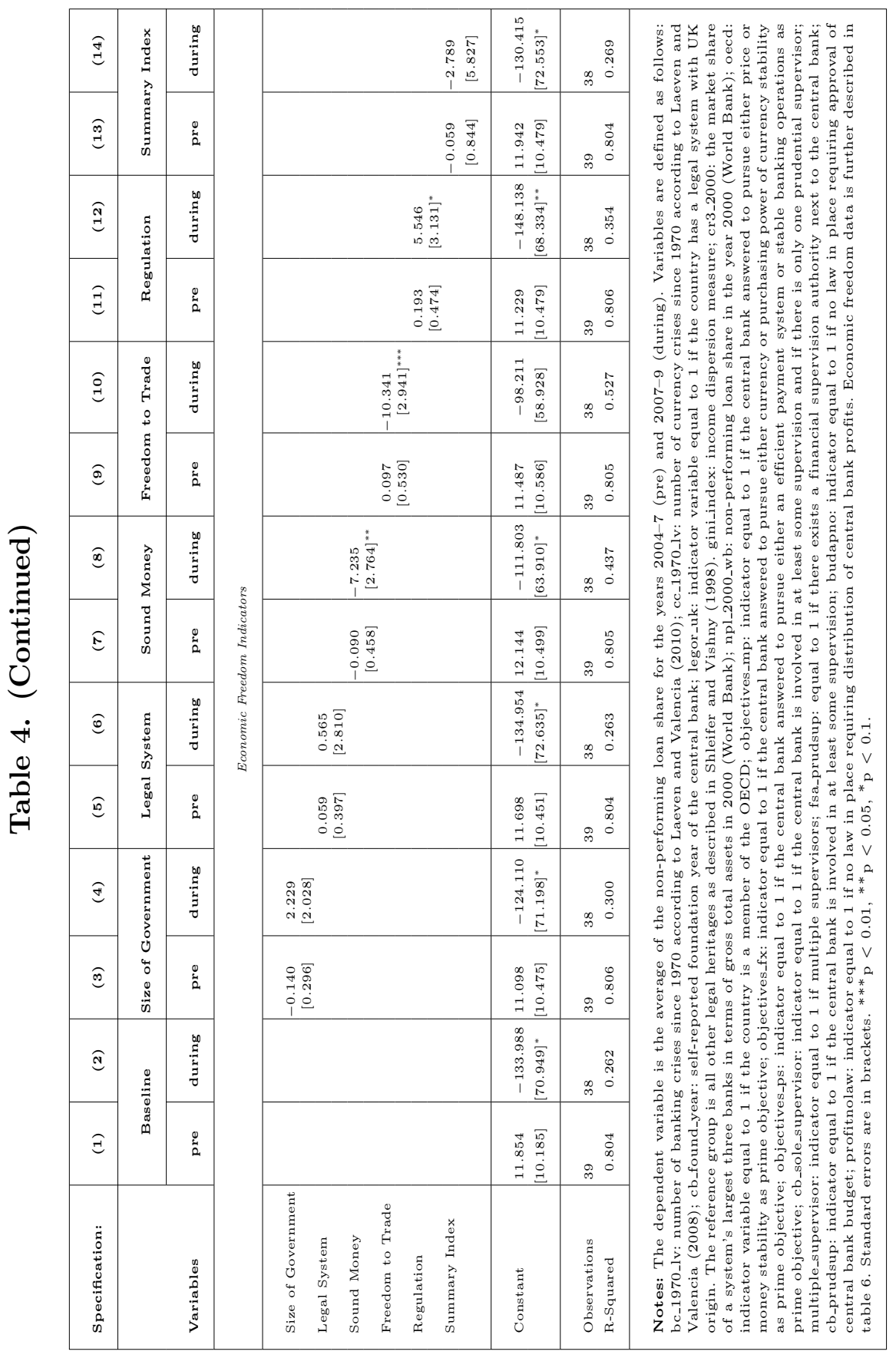




\section{Table 5. Correspondence of Currency Objectives and Past IMF Exposure 1963-2005}

\begin{tabular}{|c|c|c|c|}
\hline \multirow[b]{2}{*}{ IMF } & \multicolumn{3}{|c|}{ FX Objective } \\
\hline & NO & YES & Total \\
\hline NO & 28 & 1 & 29 \\
\hline YES & 6 & 5 & 11 \\
\hline Total & 34 & 6 & 40 \\
\hline \multicolumn{4}{|c|}{$\begin{array}{l}\text { Notes: The table shows tabulation of IMF and FX-objective indicators. IMF is equal } \\
\text { to } 1 \text { if the share of years with IMF support measures for a country is larger than } \\
\text { the } 75 \text { th percentile of the distribution of the share of years with support of all years } \\
\text { since } 1964 \text {. This share percentile is equal to } 28 \text { percent. FX objective is equal to } 1 \text { if } \\
\text { the central bank answered to pursue stability of the currency or purchasing power of } \\
\text { the currency. The area under the receiver operating characteristics curve is } 0.71 \text {. The } \\
\text { standard error is } 0.081 \text {. Thus, this area is different from either } 0.5 \text { (non-determinacy) } \\
\text { or } 1 \text { (perfectly deterministic). }\end{array}$} \\
\hline
\end{tabular}

independently. The result may be positive spillovers to local authorities, which eventually helps them in supervising their own financial systems according to mimicked standards and procedures.

Obviously, a full-fledged statistical test of this narrative is beyond the scope of this paper. It would require detailed information on actual IMF missions as well as more direct data proxying for potential skill transfers and, ultimately, adoption of better procedures, governance, and policymaking with domestic authorities.

But as an exploration of this potential reason why foreign stability objectives correlate significantly with lower shares of NPL, we manually collected from IMF annual reports the outstanding volumes of support funding to any of our sampled countries between 1964 and 2005, i.e., just up to the first period included in the precrisis mean NPL share. On average, countries in our sample had in 19 percent of the years since 1964 an exposure to the IMF. Interestingly, despite the large share of OECD countries in our sample, only seven out of forty-four countries never had an exposure to the IMF. We define intensive IMF exposure countries as those that have an exposure above the 75th percentile of the frequency distribution, i.e., in more than 28 percent of the years between 1964 and 2005 .

Table 5 shows the tabulation between high (low) IMF exposure countries and the existence (absence) of foreign stability objectives 


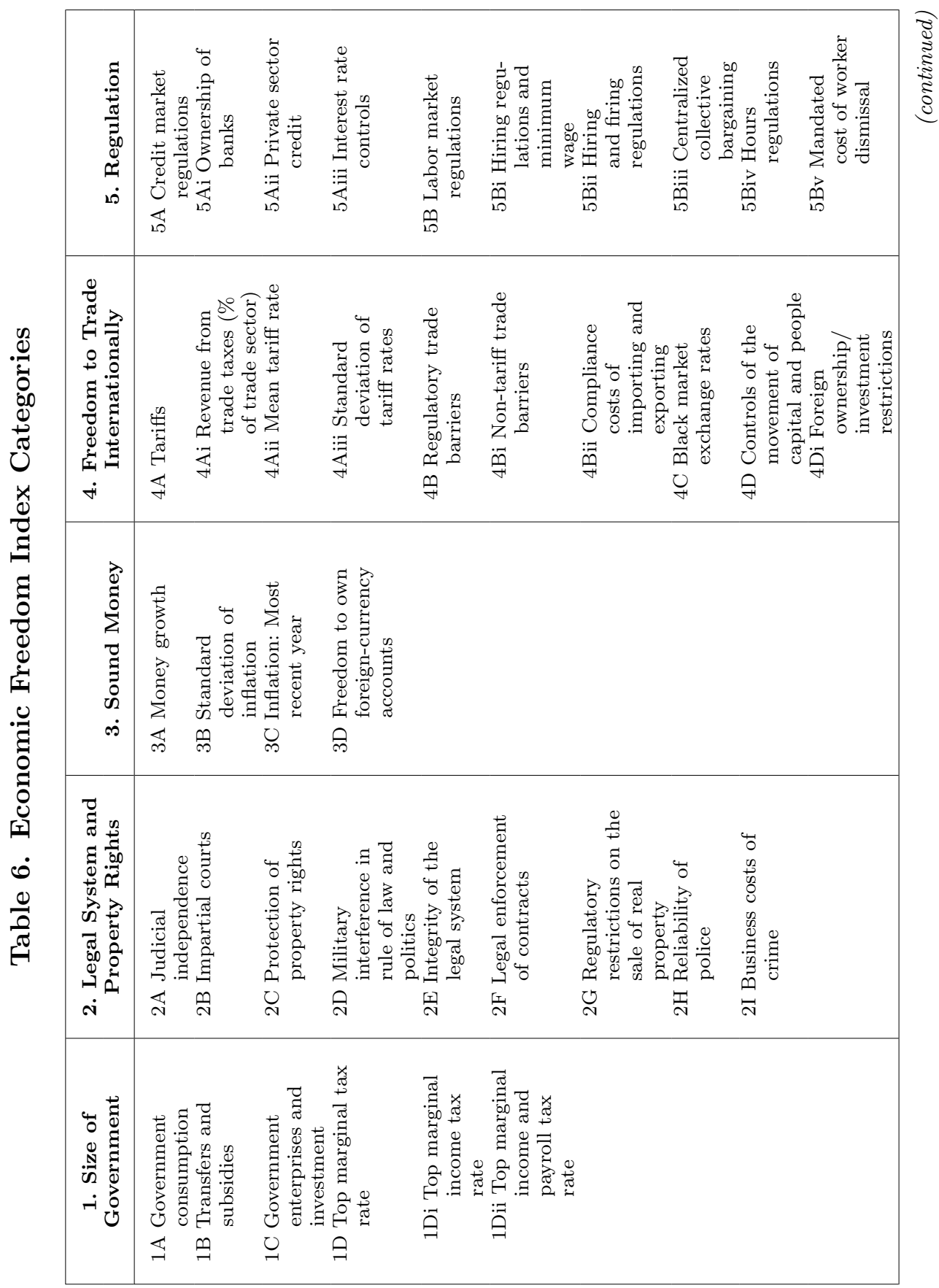




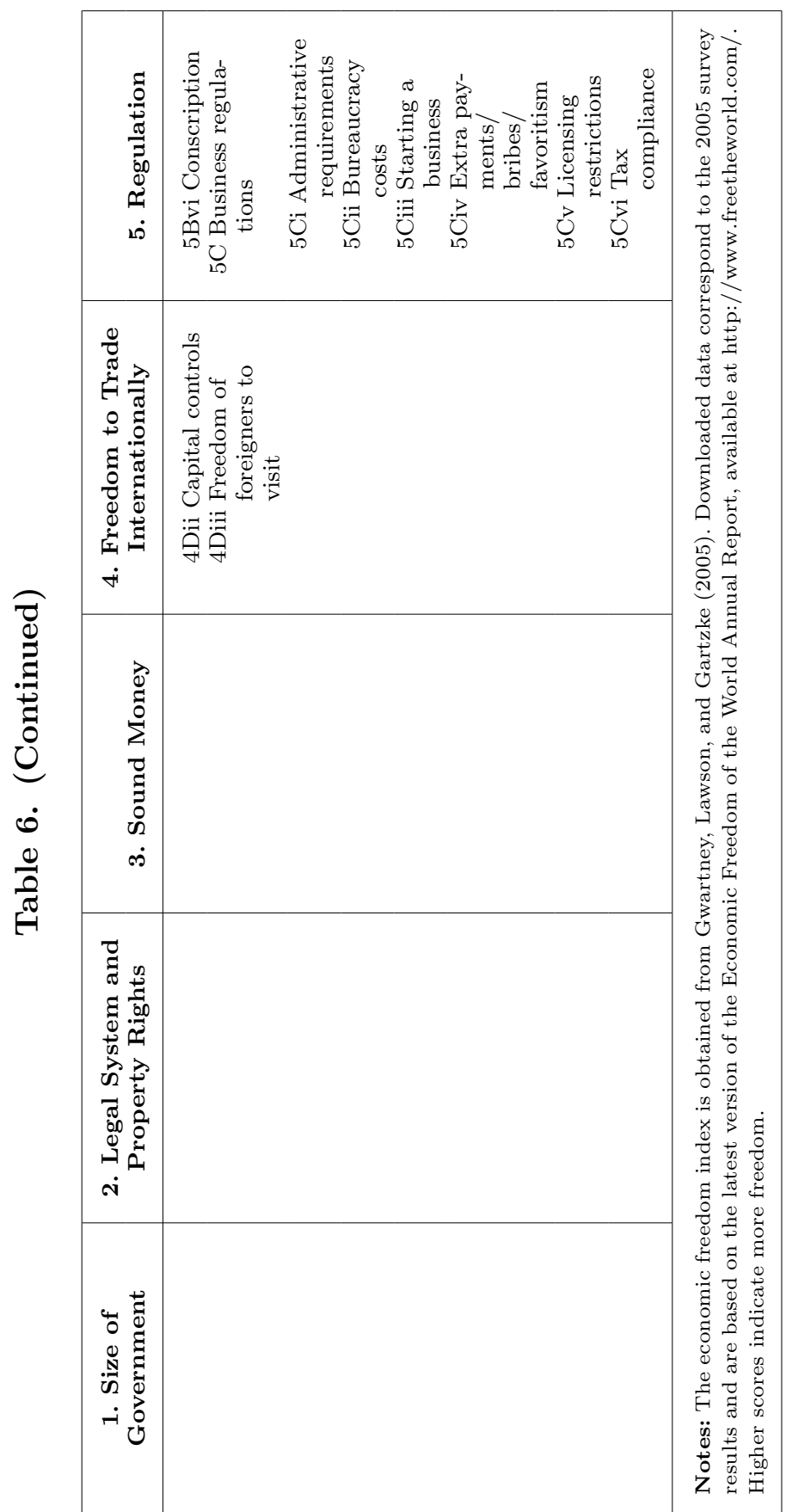


for the countries included in specifications (2) through (6) in preceding multivariate analyses. Around half of the countries with the most substantial IMF exposure also indicated the pursuit of foreign exchange stability as an objective. In turn, 83 percent of all countries indicated foreign exchange stability objectives were also exposed most frequently to the IMF. The area under the ROC curve is 0.71 - according to Hosmer and Lemeshow (2005), an indication of a good discriminatory power of these two measures. The five countries in the lower right cell of the tabulation are Argentina, Brazil, Bulgaria, Chile, and Mexico. Many of these countries actually experienced currency crises in the past, on average two since 1990 and around four since 1970 according to the crisis definitions of Laeven and Levine (2010).

Consequently, past experiences of crisis that brought in some external disciplining device in the form of IMF missions might have a more relevant long-run effect on improving prudential attitudes compared with the currently debated issues on whether or not to centralize supervision and, if so, with whom the prudential mandate should rest, central banks or financial stability authorities. Note, however, that we are not able to detect a significant relationship of an IMF exposure indicator variable on the NPL share prior to, or during the crisis for this fairly confined, cross-sectional sample. Therefore, further research into the effects of skill transfer and externally imposed discipline might constitute an important, but so far neglected, route for further research on the relation between prudential supervision and financial stability.

\section{Conclusion}

The crisis in the sub-prime mortgage market and the subsequent financial crisis ignited a debate about the past and future role of central banks and financial supervisory agencies. In several countries, new laws have been or are being adopted that alter the objectives of central banks, change the allocation of prudential supervisory authority, or change the governance structure of central banks.

In this paper, we use newly collected survey data on the governance structure of central banks in forty-seven developed and emerging jurisdictions, to shed more light on whether the formal objective, 
the mandate, and a large number of governance features of a central bank can help explain a country's banking system fragility, both prior to and during the 2007-9 financial crisis. We focus in particular on empirical evidence of whether micro-prudential supervision should be with the central banks or with a separate independent agency, as the issue is at the core of the current policy debate.

We find that neither having formal responsibility for banking supervision or banking system stability nor other central bank governance features explain cross-country variation in financial fragility, both prior to and during the crisis. Instead we find a country's legal origin, income dispersion, historical levels of credit risk, and OECD membership explain most of the variation in pre-crisis financial fragility. During the crisis period, however, these links break down.

The only governance characteristic that exhibits a significant relation with non-performing loan levels is whether central banks pursue a currency stability objective. This effect is amplified for countries with more frequent exposures to IMF missions in the past.

These results suggest that the current focus of policy discussions on whether prudential supervision should be shared or concentrated at the central bank may be somewhat misguided. Our results do not lend support in favor of institutional reforms in this direction.

Instead, one way to interpret our results is that countries that are experiencing a big crisis and are exposed to IMF crisis packages tighten up their financial supervision and reduce financial fragility, irrespective of their central bank's governance structure. Unfortunately, our data lack time-series variation and do not allow us to further investigate this matter. Additional work on the subject, starting from the data-collection stage, is needed to support policymakers and guide the design of any institutional reforms.

\section{References}

Bank for International Settlements. 2004. Electronic Compendium on Central Bank Governance. BIS Central Bank Governance Forum. Available at www.bis.org/hub/cbgf.htm (downloaded November 25, 2004).

\footnotetext{
BIS central bank hub, www.bis.org/regauth.htm.
} 
Barro, R. J., and D. B. Gordon. 1983. "Rules, Discretion and Reputation in a Model of Monetary Policy." Journal of Monetary Economics 12 (1): 101-21.

Barth, J. R., G. Caprio, Jr., and R. Levine. 2004. "Bank Regulation and Supervision: What Works Best?" Journal of Financial Intermediation 13 (2): 205-48.

Beck, T., A. Demirgüç-Kunt, and R. Levine. 2006. "Bank Supervision and Corruption in Lending." Journal of Monetary Economics 53 (8): 2131-63.

Berger, H., V. Nitsch, and T. Lybek. 2006. "Central Bank Boards around the World: Why Does Membership Size Differ?" IMF Working Paper No. 06/281.

Boot, A. W. A., and A. V. Thakor. 1993. "Self-Interested Bank Regulation." American Economic Review 83 (2): 206-12.

Boyer, P., and J. Ponce. 2012. "Regulatory Capture and Banking Supervision Reform." Journal of Financial Stability 8 (3): 206-17.

Buiter, W. H. 2011. "Accountability of the Bank of England." Supplementary written material submitted to the UK Parliament.

Davies, H., and D. Green. 2010. Banking on the Future: The Fall and Rise of Central Banking. Princeton, NJ: Princeton University Press.

Demirgüç-Kunt, A., L. Laeven, and R. Levine. 2004. "Regulations, Market Structure, Institutions, and the Cost of Financial Intermediation." Journal of Money, Credit and Banking 36 (3): 593622.

Di Noia, C., and G. Di Giorgio. 1999. "Should Banking Supervision and Monetary Policy Tasks Be Given to Different Agencies?" International Finance 2 (3): 361-78.

Eijffinger, S. C. W., and M. Hoeberichts. 2002. "Central Bank Accountability and Transparency: Theory and Some Evidence." International Finance 5 (1): 73-96.

Frisell, L., K. Roszbach, and G. Spagnolo. 2008. "Governing the Governors: A Clinical Study of Central Banks." CEPR Discussion Paper No. 6888.

Giannone, D., M. Lenza, and L. Reichlin. 2011. "Market Freedom and the Global Recession." IMF Economic Review 59 (1): 11135 . 
Goodhart, C. 2010. "The Changing Role of Central Banks." BIS Working Paper No. 326 (November).

Guiso, L., P. Sapienza, and L. Zingales. 2007. "The Cost of Banking Regulation." EUI Working Paper No. ECO 2007/43.

- 2008. "Trusting the Stock Market." Journal of Finance 63 (6): $2557-2600$.

Gwartney, J., R. Lawson, and E. Gartzke. 2005. Economic Freedom of the World: 2005 Annual Report. Fraser Institute.

Hasan, I., and L. J. Mester. 2008. "Central Bank Institutional Structure and Effective Central Banking: Cross-Country Empirical Evidence." Comparative Economic Studies 50 (4): 620-45.

Haubrich, J. G. 1996. "Combining Bank Supervision and Monetary Policy." Economic Commentary (Federal Reserve Bank of Cleveland) (November).

Herrero, A. G., and P. del Rio. 2005. "Central Banks as Monetary Authorities and Financial Stability." In Handbook of Central Banking and Financial Authorities in Europe: New Architectures in the Supervision of Financial Markets, ed. D. Masciandaro, chapter 1. Edward Elgar Publishing.

Hosmer, D. W., and S. Lemeshow. 2005. Applied Logistic Regression, Second ed. John Wiley \& Sons, Inc.

Kahn, C. M., and J. A. C. Santos. 2005. "Allocating Bank Regulatory Powers: Lender of Last Resort, Deposit Insurance and Supervision." European Economic Review 49 (8): 2107-36.

Keefer, P., and D. Stasavage. 2001. Checks and Balances, Private Information, and the Credibility of Monetary Commitments. World Bank Publications.

Keeley, M. 1990. "Deposit Insurance, Risk, and Market Power in Banking." American Economic Review 80 (5): 1183-1200.

Koetter, M., and T. Poghosyan. 2009. "The Identification of Technology Regimes in Banking: Implications for the Market PowerFragility Nexus." Journal of Banking and Finance 33 (8): 141322.

Kydland, F. E., and E. C. Prescott. 1977. "Rules Rather than Discretion: The Inconsistency of Optimal Plans." Journal of Political Economy 85 (3): 473-91.

Laeven, L., and F. Valencia. 2010. "Resolution of Banking Crises: The Good, the Bad, and the Ugly." IMF Working Paper No. $10 / 146$. 
La Porta, R., F. Lopez-de-Silanes, A. Shleifer, and R. W. Vishny. 1998. "Law and Finance." Journal of Political Economy 106 (6): $1113-55$.

Lybek, T., and J. Morris. 2004. "Central Bank Governance: A Survey of Boards and Management." IMF Working Paper No. $04 / 226$.

Martínez Miera, D., and R. Repullo. 2010. "Does Competition Reduce the Risk of Bank Failure?" Review of Financial Studies 23 (10): 3638-64.

Moser, P. 1999. "Checks and Balances, and the Supply of Central Bank Independence." European Economic Review 43 (8): 1569-93.

Peek, J., E. Rosengren, and M. B. Tootell. 1999. "Is Bank Supervision Central to Central Banking?" Quarterly Journal of Economics 114 (2): 629-53.

Persson, T., and G. Tabellini. 1993. "Designing Institutions for Monetary Stability." Carnegie-Rochester Conference Series on Public Policy 39 (1): 53-84.

Rogoff, K. 1985. "The Optimal Degree of Commitment to an Intermediate Monetary Target." Quarterly Journal of Economics 100 (4): 1169-89.

Schoenmaker, D. 1992. "Institutional Separation between Supervisory and Monetary Agencies." Special Paper No. 52, Financial Markets Group.

Stolz, S. M., and M. Wedow. 2010. "Extraordinary Measures in Extraordinary Times. Public Measures in Support of the Financial Sector in the EU and the United States." ECB Occasional Paper No. 117.

Taylor, M., and M Quintyn. 2002. "Regulatory and Supervisory Independence and Financial Stability." IMF Working Paper No. $02 / 46$.

Walsh, C. E. 1995. "Optimal Contracts for Central Bankers." American Economic Review 85 (1): 150-67.

World Bank, World Development Indicators (WDI) and Global Development Finance (GDF) database. Available at http:// databank.worldbank.org/data/home.aspx. 